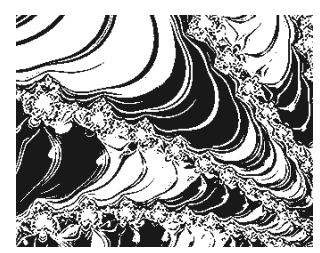

https://doi.org/10.5559/di.30.2.09

\title{
INFODEMIOLOGICAL STUDY ON THE USE OF FACE MASKS DURING COVID-19: COMPARING U.S. AND KOREA
}

Jin- $\mathrm{A} \mathrm{CHOI}$

William Paterson University of New Jersey, Wayne, New Jersey

Sejung PARK

Pukyong National University, Busan, South Korea

UDK: 614.446/.447(519.5+73):[616.98:578.828COVID-19]"2020"

614.891(519.5+73):[616.98:578.828COVID-19]"2020"

614.446/.447(519.5+73):004.738.5"2020"

Izvorni znanstveni rad

Primljeno: 19. 8. 2020.

In the midst of the COVID-19 pandemic, there have been varied responses to public health officials' recommendations about wearing face masks as a means to slow the spread of the virus. This study, by using Twitter data, aims to explore the role of digital technology in facilitating public conversations and formulating public perception regarding face masks during the COVID-19 pandemic in two contrasting contexts: the U.S. and South Korea. From January 1, 2020 to April 14, 2020, a total of 22,928 users generated 27,501 tweets regarding face masks in the U.S. network, whereas 17,267 users produced 18,686 tweets in that of South Korea. The results of the semantic network analysis shed light on Americans' initial resistance to wearing masks as well as Koreans' willingness to comply. Details of the results are discussed further in the paper. With real-time data aggregation, this study gives insight into the rising controversy regarding wearing face masks during COVID-19 while providing implications for health officials designing strategic communication messages.

Keywords: infodemiology, COVID-19, coronavirus, face masks, Twitter, social network

Corresponding author: Sejung Park, Pukyong National University, 48513, Busan, South Korea. 
DRUŠ. ISTRAŽ. ZAGREB GOD. 30 (2021), BR. 2, STR. 359-378

CHOI, J.A., PARK, S.: INFODEMIOLOGICAL...
The Coronavirus pandemic has been sweeping the globe for nearly a year to date. The disease has created a social environment that induces fear, insecurity, and stress in the general public, which threatens physical and mental health. Therefore, since the outbreak of the novel disease (COVID-19), there has been strategic communication on multiple levels, global, national, and local, to assuage the public's fear and panic, provide information to help slow the spread of the virus, give updates on new infections and deaths, and assist the state and national authorities in providing responses and action plans for managing COVID-19.

In the United States, the Centers for Disease Control and Prevention (CDC) has taken the most prominent role in communicating safety and addressing COVID-19's threats to the public. There have been several preventive measures aimed at preventing the spread of COVID-19, such as self-isolation, social distancing, habitual use of hand sanitizer, and wearing face masks. However, despite public health officials' efforts to promote these changes, it is evident that there is resistance to wearing face masks in the U.S. In contrast to other countries around the globe that have accepted wearing face masks as a social norm, the U.S. still faces protests and online debates regarding the effectiveness of face masks, rejection of government mandates, refusal to wear masks, among others (Prasad, 2020). The U.S.'s resistance to wearing face masks, despite public health experts' recommendations, has gained worldwide attention. While there are speculations regarding reasons why Americans are refusing to wear masks, the exploration of online public dialogues and debates on this issue has yet to be conducted.

On the other hand, South Korea, where COVID-19 has been successfully managed, has been receptive to wearing masks. Thus, examination of public discourse and attitudes regarding face masks in these two contrasting contexts can provide a timely opportunity to observe information sharing behaviors, public perception, and salient issues regarding face masks. With this aim, we explore the role of digital technology by conducting an infodemiological study (ie. Information epidemiology), an emerging area of research on distribution of health data, information trends, and users' information behaviors to inform health professionals and policy-makers (Eysenbach, 2009). Real-time aggregation of health-related information generated and shared by the public via social media can reflect the public's health status, concerns, awareness, as well as discover related issues regarding diseases (Park et al., 2020). The large corpus of public health data shared on social media during pandemics provides an opportunity to observe the pub- 
lics' thoughts and opinions regarding public health interventions and recommendations to reduce personal risks (Park et al., 2020).

\section{RISK COMMUNICATION AND PUBLIC ATTITUDES TOWARD FACE MASKS IN THE U.S.}

Without a vaccine, there are only two ways in which the spread of COVID-19 can be prevented, social distancing and wearing a face mask (Chung, 2020). While it is evident that the virus is extremely contagious, only social distancing of 6-feet has been adopted in the U.S. as a socially responsible behavior. The reasons for the public's resistance toward wearing masks may vary, but communication from health authorities may have built a stigma toward wearing face masks in public. For example, the announcement on February 2020 by the CDC and the U.S. Department of Health and Human Services recommended that "people shouldn't wear face masks to prevent the spread of the infection illness" (Buchwald, 2020). While the government may have feared a shortage of masks for health care providers, the public feared for their own safety. Americans did not heed to public health experts' advice and stores nationwide sold out of face masks instantly (Buchwald, 2020). Furthermore, it was also recommended that only those who are symptomatic should wear a mask (Blaker, 2020). Not only did this misinformation give the public the incorrect assumption that anyone wearing a mask is infected, but it may have also discouraged people from wearing a mask in fear of their safety.

Notably, those wearing masks in large metropolitan areas such as New York City and Los Angeles, became targets of hate crime and xenophobic attacks (Yan et al., 2020). Due to the "presumed criminality of black men in general," (Alfonson III, 2020) and the historical discrimination of Muslim women in niqabs (Perolini, 2020), face coverings have been commonly associated with negative connotations such as thieves, gangs, terrorists, and foreigners. Therefore, minority groups and African Americans feared for their safety as racial profiling may have been heightened with face coverings. Furthermore, when it was discovered that some infected individuals may be asymptomatic or that there is a 14-day incubation period prior to showing symptoms, the public began to question the credibility of the messages coming from health authorities. The public was not only misguided with misinformation for months, but they had been facing physical violence and safety issues when health officials changed their narrative and began to recommend and enforce face masks in public.

In June 2020, the CDC started recommending that anyone over the age of two should wear cloth face coverings in 
DRUŠ. ISTRAŽ. ZAGREB GOD. 30 (2021), BR. 2, STR. 359-378

CHOI, J.A., PARK, S. INFODEMIOLOGICAL.. public (Centers for Disease Control and Prevention, 2020c). The inconsistency in health authorities' communication caused further confusion and skepticism toward their messages. Despite the alarming severity of the Coronavirus outbreak, it seems that the mixed-messages from the nation's public health agency have given rise to a controversy that is countered by the public beyond reason and cause of a national security threat. Even though public health experts are continuing to urge people to wear masks, and the government is enforcing face masks to be worn in public, there is still strong pushback from the public. Discussions surrounding the face masks' ability to protect from and prevent transmission of the Coronavirus are still being popularly debated.

\section{RISK COMMUNICATION AND PUBLIC ATTITUDES TOWARD FACE MASKS IN SOUTH KOREA}

Months before the U.S. became an epicenter of COVID-19, South Korea led the world with surging cases of the disease, closely behind China. Despite the aggressive spread of the novel virus, South Korea quickly contained the virus within a month and now ranks 67th worldwide in confirmed cases (World Health Organization, 2020). South Korea has been praised globally as a model for how other countries should be dealing with the pandemic (Pannell, 2020), especially in their proactive testing and tracing of COVID-19, as well as mass production, distribution, and promotion of face masks (Chung, 2020). A notable difference between the U.S. and South Korea may be in the way the nation and the public regarded face masks. The government gave a coherent message, encouraging all to wear masks in public. To avoid panic of shortages, the sales of masks were rationed (Rubin, 2020). Additionally, despite the fact that face masks were not mandated, it became a social norm. Since the Middle East Respiratory Syndrome (MERS-CoV), a similar viral respiratory infection caused by a novel coronavirus, had already swept South Korea in 2015, and the practice of wearing masks to protect against air pollution (Chung, 2020) was already in place, South Koreans were already accustomed to wearing face masks prior to COVID-19. Therefore, the public may have quickly accepted and adopted wearing face masks.

Meanwhile, COVID-19 is continuing to spread worldwide with threats of variants in countries where it appears to have been contained. Therefore, it is important to understand public discourse regarding one of only two ways in which the infection can be prevented. Understanding the public's attitude toward wearing masks, and the comparison of responses to masks in the U.S. and South Korea may give health officials insights on how to best communicate with its publics during this pandemic. 
One may presume that all publics would comply universally with recommendations given by global health officials. However, receptivity to communication often varies by culture (Choi \& Lewis, 2017); thus, according to the cultural dimensions theory (Hofstede, 1984), responses to prevention recommendations may also differ between Koreans and Americans. Whereas individualistic cultures (e.g. United States) emphasize autonomy, collectivistic cultures (e.g. Korea) emphasize interdependence and group well-being (Hofstede, 1984). In this sense, the characteristics of following social standards and group values may have allowed Koreans to quickly adopt pro-mask wearing behavior as a social norm and a socially responsible behavior. Additionally, higher-context cultures, such as Korea, prefer to adopt information from situations or their cultural environment (Hall, 1976). Subsequently, as group norms are more salient in Koreans, they are more likely to acquiesce to socially set standards and pressures to avoid criticism associated with socially unacceptable behaviors. Group norms and values are usually set by high-status individuals (Hofstede, 1984). As public health authorities are deemed to be experts whom the public would presumably look to for advice, Koreans may be more likely to adhere to the pandemic norms and regulations set by government and health officials.

On the other hand, the cultural dimensions theory lends that Americans may not necessarily comply with recommendations that come from high-status experts despite the pandemic, as they are individualistic in culture (Hofstede, 1984). It may be more difficult to create a new social norm in cultures where there is a stronger preference toward autonomous decision-making. Enforcing pandemic norms and regulations may be more difficult to achieve for Americans, who do not necessarily feel the need to heed to social norms. Additionally, according to the information context theory (Hall, 1976), it is also important to note that low-context cultures (e.g. United States) prefer to communicate more explicitly. Americans may have been hesitant to adopt prevention recommendations due to the non-explicit nature of the communication from health officials, especially with misleading information and changing narratives. As it is the norm to verbalize direct and clear messages (Würtz, 2005) in the U.S., unclear direction or misinformation given by the government may have led not only to confusion but fear and uncertainty, resulting in initial resistance and anti-mask behaviors. 
Infodemiology is a growing area of research that helps to inform public health officials in order to develop public policies by using informatics in the analysis of online health data (Eysenbach, 2009). It allows the examination of health data in real-time through unstructured textual, graphics or user-generated information through various online media outlets (Eysenbach, 2011). Although the credibility of online information from ordinary users may be questionable, such data from Twitter and Facebook have been shown to complement traditional epidemiological data and methods which may be more time-consuming, resulting in delayed responses (Bragazzi et al., 2017). Therefore, the examination of the public's responses to health officials' communication framing via social media may give insight into the public's subsequent perceptions and attitude formation (Alicino et al., 2015). Furthermore, the application of social network analysis to risk communication is crucial as it helps find the structure of knowledge and information sharing networks (Bragazzi et al., 2017), identify source distribution (Eysenbach, 2006), track collaborative networks (Achrekar et al., 2012), and find multi-level interaction patterns among users (Bragazzi et al., 2017). Such perception-based information not only informs public health officials in real-time, but also aids in the design of new public health campaigns, policies and interventions that will likely be well-accepted by the public.

Social media, such as Twitter, has enabled the public to share their opinions in a variety of contexts, creating a huge amount of publicly available user-generated data on trending topics. Data mining of tweets provides an efficient way to survey a large number of participants in real-time. Therefore, Twitter has provided new opportunities for researchers examining public opinion in a wide array of timely topics, such as political campaigns and elections (Karami et al., 2018), climate change sentiment (Cody et al., 2015), vaccinations (Tavoschi et al., 2020), targeted advertising (Hong et al., 2021), and public health crises such as the Ebola outbreak (Lazard et al., 2015).

Twitter, a microblogging site, is also known to effectively show networking trends in the public's conversations and information-sharing behavior, especially during pandemics (Park et al., 2020). A recent study found that the number of tweets against mask-wearing is correlated to the number of new COVID-19 cases (Al-Ramahi et al., 2021). This implies that monitoring Twitter conversations and debates is useful in investigating public concern, key issues, and barriers related to wearing face masks, which can ultimately help manage the spread of COVID-19. Therefore, this study examines public conversations on Twitter to address the following research questions: 
DRUŠ. ISTRAŽ. ZAGREB GOD. 30 (2021), BR. 2, STR. 359-378

CHOI, J.A., PARK, S.: INFODEMIOLOGICAL..

\section{METHOD}

\section{Data Collection}

RQ1: How do Americans and Koreans disseminate information and engage in the public dialogue about face masks on Twitter during the Covid-19 pandemic?

RQ2: What are the salient issues and topical trends in the American and Korean public discourse regarding face masks on Twitter during the COVID-19 pandemic?

RQ3: What are the major themes in the American and Korean public discourse about face masks on Twitter during the COVID-19 pandemic?

This study comparatively examines communication networks and public perceptions between the U.S. and South Korea on wearing face masks during the COVID-19 pandemic using Twitter data. Twitter is one of the largest social media sites in the U.S. and Korea and provides useful public health data, especially during infectious disease outbreaks (Park et al., 2020). Tweets about face masks related to COVID-19 in English and Korean, from January 1 to April 14, 2020, were collected from the Twitter search applications programming interface (API) using NodeXL. Soon after a cluster of COVID-19 infection cases were reported in Wuhan City in China for the first time, on December 30, 2019, the CDC began responding to the novel coronavirus in early January 2020 (Centers for Disease Control and Prevention, 2020a). The study's time period captures the first three months of the coronavirus disease. As people have limited experience and cultural resistance to face coverings in the western culture, wearing face masks was highly debated in the initial phase of the COVID-19 pandemic (Prasad, 2020). Thus, investigation of public discourse surrounding face masks during this time period helps to understand key issues and initial perceptions about adopting wearing face masks as a preventive measure from the publics' perspective.

The queries, "mask" or "N95" (qualified by the U.S. National Institute for Occupational Safety and Health) in English, and the equivalent in Korean, "마스크" or "KF98," (equivalent to N95 in Korea) were used. Any posts unrelated to COVID-19 or tweets from geographic locations other than the U.S. and Korea were filtered out. Our final sample comprises of 46,187 relationships between 40,195 users, which includes original tweets, retweets, replies to, and mentions, in Twitter networks $(27,501$ relationships between 22,928 users from the 
U.S. network and 18,686 relationships between 17,267 users from the Korean network).

\section{Social and Semantic Network Analysis}

This study conducted social and semantic network analyses to comparatively determine how information regarding face masks, during the COVID-19 pandemic, is disseminated on Twitter in the U.S. and Korea. Additionally, how public perceptions and attitudes toward face masks as a protective equipment differ between the two countries was also examined. Social network analysis was conducted to examine the flow of communication about face masks in the COVID-19 pandemic between the users and the pattern of interaction between users embedded in the Twitter networks.

Various network measures were computed to quantify the structural properties of networks and multidimensional communication activities between users using NodeXL and the UCInet6 software. The network measures include density, centralization, the number of self-loops, and connected components, and eigenvector centrality values. The density is an indicator of the extent of connectedness between users in a network (Borgatti et al., 2002). Components refer to subgraphs that represent connected nodes through paths (Wasserman \& Faust, 1994). A self-loop occurs in Twitter networks when the user gets no replies or mentions from other users. A cluster analysis was conducted to classify subgroups that were closely connected to each other in the networks using the ClausetNewman-Moore cluster algorithm (Clauset et al., 2004). Eigenvector centrality index was also computed that gauges the influence of a node in a network by assessing relative ranking of a node based on its connection to central nodes in a network (Bihari \& Pandia, 2015). In addition, the topography of the networks was visualized using the Harel-Koren Fast Multiscale layout algorithm from NodeXL.

To investigate public perceptions and attitudes toward face masks from public conversations on Twitter, we also employed a semantic network analysis, which is useful for investigating large volumes of qualitative data. Semantic network analysis is a meaning-centered network approach to detecting prominent issues, metaphors, and key themes based on the pattern of word co-occurrences in a text corpus (Park et al., 2016). NodeXL was employed to generate co-occurrence matrices of the top 100 word-pairs and semantic network visualizations. In-depth investigation of clusters in semantic networks allows identification of key issues related to face masks and shared meanings about the key issues from the public's perspectives (Davidson et al., 2019). 


\section{RESULTS}

\section{The flow of information and conversational patterns during the COVID-19 pandemic}

() TABLE 1

Structural properties of information transmission networks on Twitter
We compared the flow of information transmission and the pattern of interactions between users in the U.S. and Korea Twitter issue networks, regarding face masks during the COVID-19 pandemic. Table 1 summarizes the structural characteristics of each issue network.
U.S.

Network measures

Twitter network
Nodes, $\mathrm{n}$

Total Edges, $\mathrm{n}$

Unique Edges, n (\%)

Edges with Duplicates, n (\%)

Self-loops, n (\%)

Connected Components, $\mathrm{n}$

Maximum Edges in a Connected Component, $\mathrm{n}$

Clusters, $\mathrm{n}$

Average Geodesic Distance

Reciprocated Edge Ratio

Density

$\begin{array}{rr}22,928 & 17,267 \\ 27,501 & 18,686 \\ 22,805(82.92) & 17,542(92.87) \\ 4,698(17.60) & 1144(6.12) \\ 3,589(13.05) & 2958(15.83) \\ 4,824 & 2,788 \\ 18,456 & 13,588 \\ 2,682 & 1,118 \\ 4.279187 & 5.892402 \\ 0.012975 & 0.013185 \\ 0.000039 & 0.000051\end{array}$

Twitter network
Korean

The results of social network analysis suggest that the U.S. network is larger than the Korean network. A total of 22,928 users generated 27,501 tweets, regarding face masks in the U.S. network, whereas 17,267 users produced 18,686 tweets in Korea. The pattern of information transmission and conversation between users is similar in both networks in which they have loosely connected, but complex structures with multiple clusters. In both networks, many conversations between actors were observed.

The majority of the tweets were interactions between users $(86.95 \%$ for the U.S. network and $84.17 \%$ for the Korean network). Less than $16 \%$ of the users were isolates who were found to not have any interactions with other users who tweeted about masks. On the one hand, the percentage of unique edges, which refers to one-time conversation, was higher in the Korean network $(92.87 \%)$ than in the U.S. network $(82.92 \%)$. On the other hand, the percentage of edges with duplicates, which indicates redundant relationships between users, was higher in the U.S. network than it was in the Korean network. Among the conversations, $17.60 \%$ interactions in the U.S. network and $6.12 \%$ in the Korean network occur between the same users more than once regarding the face masks issue. This suggests that the U.S. users engaged more in continuous conversational threads to discuss the topic of masks than did the Korean users. 
DRUŠ. ISTRAŽ. ZAGREB GOD. 30 (2021), BR. 2, STR. 359-378

CHOI, J.A., PARK, S.: INFODEMIOLOGICAL..
However, the Korean issue network has slightly higher reciprocated edge ratios than the U.S. network, suggesting that Korean users exchanged information about mask-related issues and talked to others more than the U.S. users. Furthermore, the average geodesic distance, a measure of the required shortest path that connects the two users, was shorter in the U.S. twitter network than it was in the Korean network. While only around four steps were necessary in the U.S. network, about five steps were required to reach any other randomly chosen user in the Korean network.

The result of a component analysis indicates that the U.S. network had much larger numbers of connected components with larger maximum edges in a connected component. This means that the actors in the U.S. network had bigger discussion threads to transfer information related to masks during the COVID-19 pandemic compared to actors in the Korean network.

\section{Topical trends and distribution of keywords in the discourse about face masks during the COVID-19 pandemic on Twitter}

(1) TABLE 2

Top Keyword in

Semantic Network of the Face Masks issue
The relative influence of issues and topical trends amid the discussions surrounding face masks on Twitter during the COVID-19 epidemic in the U.S. were explored. The top $20 \mathrm{key-}$ words in terms of eigenvector centrality values in the semantic network of the public's tweets on face masks during the COVID-19 epidemic are presented in Table 2.

\section{Rank Keyword in Eigenvector Centrality Keyword in Eigenvector Centrality U.S. Network in U.S. Network Korean Network in Korean Network}

\begin{tabular}{rllll}
\hline 1 & mask & 0.150 & mask & 0.075 \\
2 & wear & 0.054 & right & 0.048 \\
3 & face & 0.047 & problem & 0.047 \\
4 & n95 & 0.042 & kindergartener & 0.047 \\
5 & respirator & 0.042 & journalist & 0.047 \\
6 & inside & 0.039 & factory & 0.047 \\
7 & glove & 0.039 & condom & 0.047 \\
8 & practice & 0.035 & protective clothing & 0.047 \\
9 & november & 0.035 & purchase & 0.047 \\
10 & yoongi & 0.033 & ear & 0.047 \\
11 & surgical & 0.033 & wear & 0.047 \\
12 & without & 0.033 & visit & 0.047 \\
13 & put & 0.033 & production manager & 0.047 \\
14 & come & 0.033 & sooho & 0.044 \\
15 & king & 0.033 & chosun school & 0.044 \\
16 & medical & 0.033 & 5day rotation system & 0.044 \\
17 & singer & 0.033 & theb & 0.044 \\
18 & felony & 0.033 & raincoat & 0.044 \\
19 & public & 0.033 & require & 0.044 \\
20 & make & 0.033 & give a ride & 0.006 \\
\hline
\end{tabular}


DRUŠ, ISTRAŽ ZAGREB GOD. 30 (2021), BR. 2, STR. 359-378

$\mathrm{CHOI}$, J.A., PARK, S.: INFODEMIOLOGICAL..
The most influential node in the semantic network was "mask" (0.150), followed by other related terms, such as "wear" (0.054), "face" (0.047), "n95" (0.042), and "respirator" (0.033). The prominence of these terms reflects people's high interest in protecting their faces. The other central words in the network include supportive messages for health care professionals and updating their status about wearing surgical masks [e.g., "medical" (0.047), "surgical" (0.033)].

As expected, the most frequent keyword associations in the U.S. network is "wear-mask" $(3,953)$. Specific types of masks and other protective gear were found to be dominant issues in public tweets such as "face-mask" $(3,602)$, "n95-mask" $(3,327)$, "mask-glove" (53), "n95-respirator" (474), "surgical-mask" (426), and "respirator"-"mask". Although the CDC recommended using cloth face coverings instead of N-95 respirators or surgical masks that should be reserved for healthcare professionals and medical first responders (Centers for Disease Control and Prevention, 2020b), the public wanted to protect themselves against the novel coronavirus by using medically effective devices.

Other salient keyword associations are "covid-19 (648)", "social-distance" (517), "feet-way" (416), "store-wear" (370), "4-feet" (355), and "community-spread" (354). These reflect the public shared health practices and means to prevent infections or further spreading of the novel coronavirus in public settings.

As shown in Table 2, the keyword distribution and the salient co-occurrence words in the Korean semantic network that emerged about wearing face masks were also investigated. In the Korean semantic network, as anticipated, "mask" (0.075) is the most central word, followed by "right" (0.048), indicating the public's positive perception about the appropriate responses by the government in dealing with the outbreak. The other central words in the network include critical voices toward domestic journalists in framing COVID-19 related news [e.g., "problem" (0.047), "journalist" (0.047)] and practical issues surrounding face masks, such as those related to production, purchase information, and wearing masks [e.g., "factory" (0.047), "production manager" (0.047), "protective clothing" (0.047), "ear" (0.047), "wear" (0.047), and "purchase" (0.047)].

The most frequent keyword pair in the Korean network is "mask-require" $(3,603)$. The next dominant word pair is "sangyeon-shine" $(3,602)$, followed by "THEB-mask" $(3,602)$, and "raincoat-mask" $(1,180)$. These words were used by fans to describe popular K-pop idols' appearances (e.g., EXO, THE BOYZ) while wearing face masks, and encouraged both celebrities and fans to wear protective equipment. Other salient keyword pairs were "well-overcome" (1180), "heart-donation" $(1,180)$, and "donation-proceed" $(1,180)$. These word pairs suggest po- 
sitive public perception about the emergency management of the government and their support for dealing with the outbreak.

\section{Major themes in the Semantic Network of face masks during the COVID-19 pandemic on Twitter}

(1) FIGURE 1

Semantic Network of Public Discourse

Regarding Face Masks on Twitter in the U.S.
Qualitative analysis of major clusters comparatively detects the major themes and public perceptions about face masks in the U.S. and Korea. The semantic network map of the issue networks regarding face masks are visualized in Figure 1 and Figure 2.

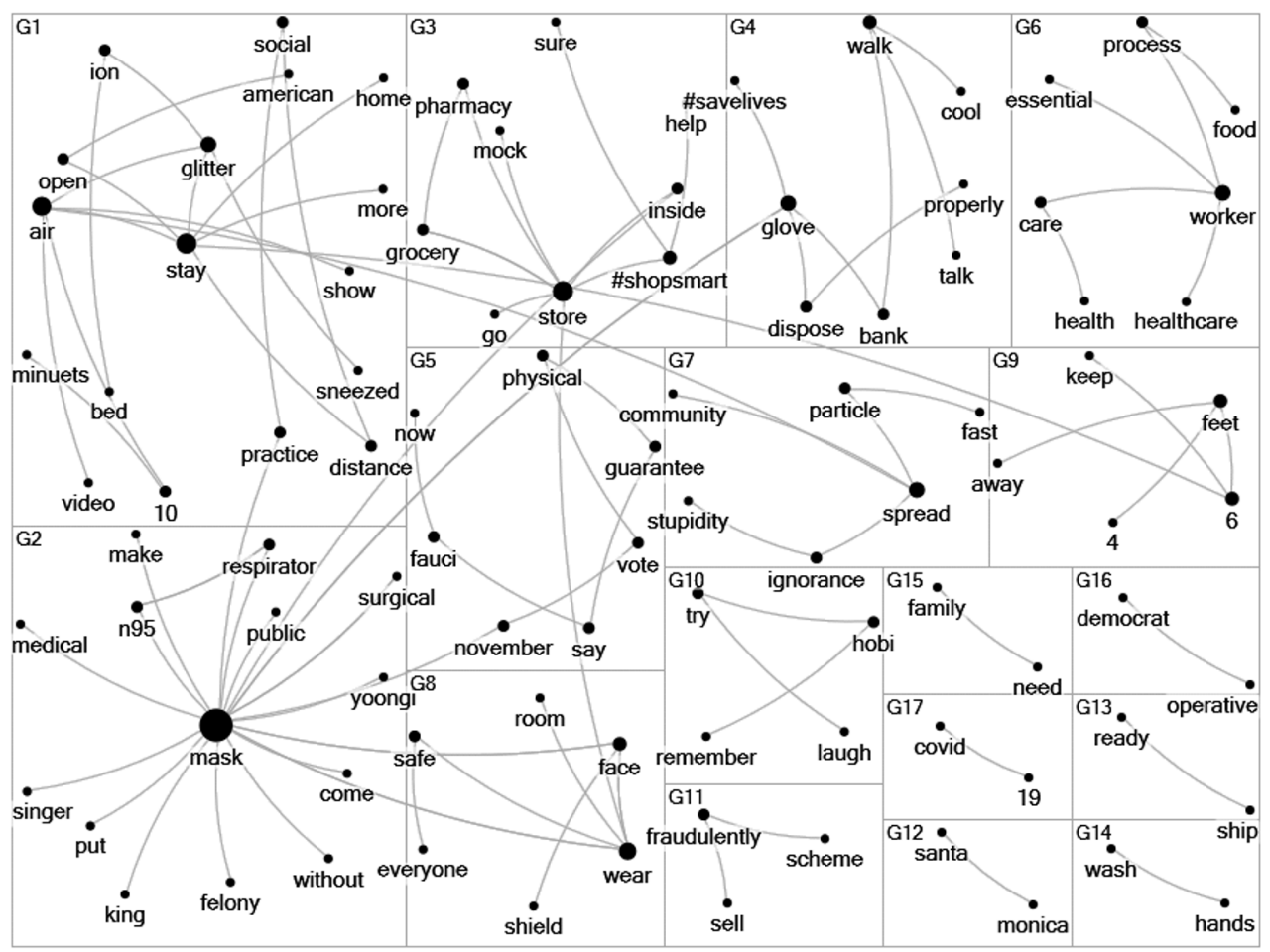

In undirected networks, each node refers to a word. The link between words indicates a co-occurrence of the two words. The size of the radius of the nodes reflects their degree values. The larger the node, the more the word is connected to other words in the network. Subgroups were classified from the cluster analysis.

As shown in Figure 1, a cluster analysis identified that the U.S. semantic network was composed of multiple layers. A total of 17 subgroups were observed. The largest cluster, G1, was about stay home recommendations, encouraging the public to wear masks with information regarding how COVID-19 is spread from person to person as well as news on how to 
DRUŠ. ISTRAŽ. ZAGREB GOD. 30 (2021), BR. 2, STR. 359-378

$\mathrm{CHOI}$, J.A., PARK, S. INFODEMIOLOGICAL..

\section{(1) FIGURE 2}

Semantic Network of Public Discourse Regarding Face Masks on Twitter in Korea make fabric masks. G2 was about important issues related to n95 masks, respirators, and surgical masks such as informing and expressing concerns regarding nurses who work without masks and the medical effectiveness of face masks during the outbreak. The other cluster, G3, was about personal episodes of wearing masks in grocery stores, pharmacies, and recommending that workers and the public at stores put masks on in public spaces. Interestingly, both "pro-maskers" and "anti-maskers" were observed. Some users were doubtful about the effectiveness of wearing masks to prevent COVID-19 or mocked people wearing masks (e.g., "You sound like you're one of those mask-wearing idiots in the grocery store. Whole debacle nothing more than media hysterics over virus with no more punch than average flu."; "I can't bring myself to panic. Maybe I should more than I do. I don't know. I go to the store. I stay away from people. I don't wear a mask or gloves.").

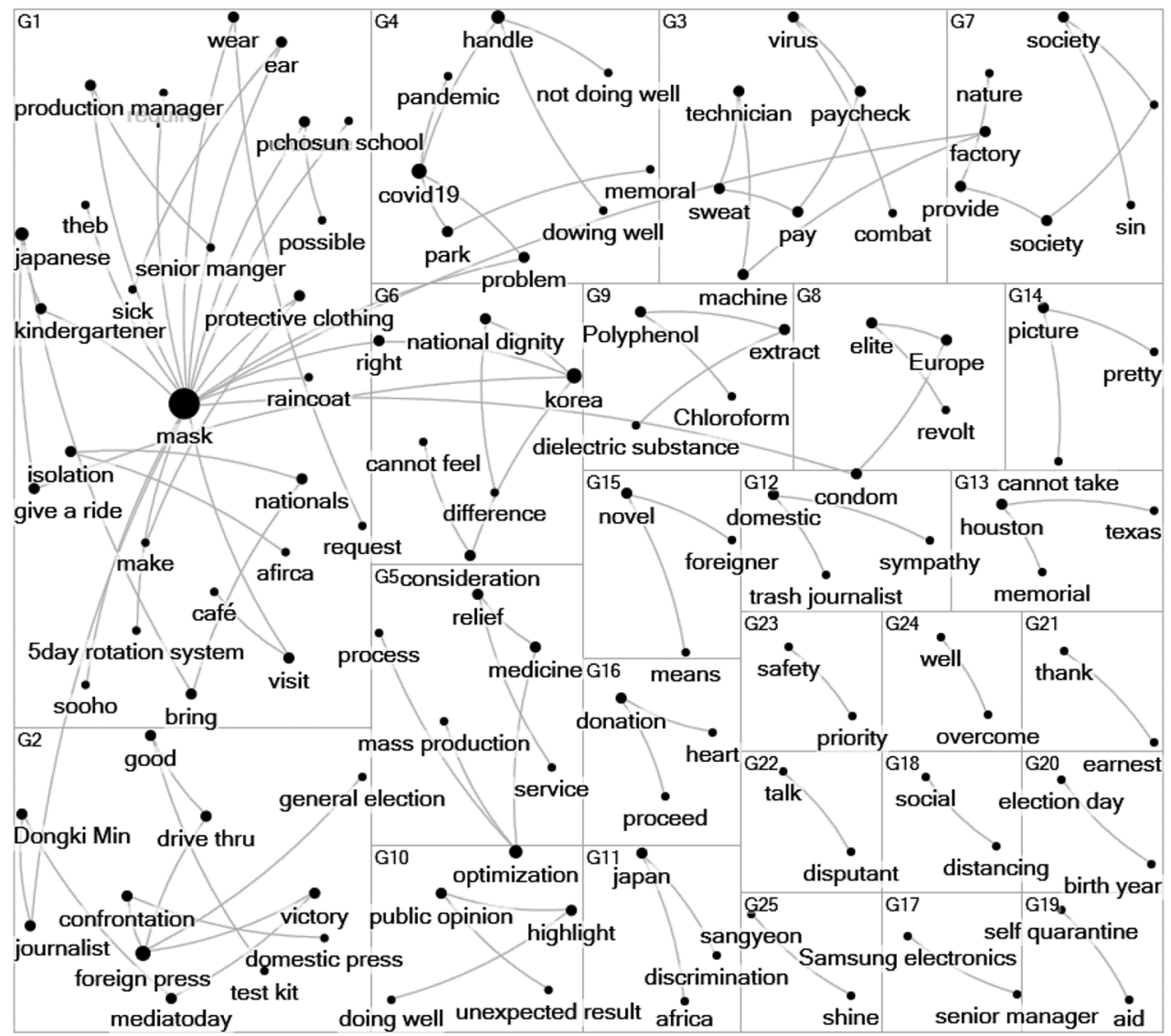

Other users shared their opinions or episodes of fights with others at grocery stores about wearing masks (e.g., "At the grocery. Wearing my mask. Lady behind me, loud enough 
DRUŠ. ISTRAŽ. ZAGREB GOD. 30 (2021), BR. 2, STR. 359-378

CHOI, J.A., PARK, S.: INFODEMIOLOGICAL.. to make sure I heard, "don't guess she realizes that stupid mask won't do any good"; "it's mandatory now be respectful and help protect me while I'm making your food").

G4, suggests wearing masks while walking and talking to others, and blaming people who do not cover their faces at banks. Interestingly, G5 consisted of a debate about the qualification of Dr. Anthony Fauci, director of the National Institute of Allergy and Infectious Diseases. Criticisms regarded his earlier underestimation of the risks related to COVID-19 in the U.S. and his position against the public wearing masks unless they were contagious (O'Donnell, 2020). The rest of the small clusters include worrying about healthcare professionals, negative sentiment toward ignorance and stupidity of those who still resist wearing masks (G7), recommendation of face shields for safety (G8), social distancing (G9), as well as describing J-Hope with a face mask, a member of BTS, the famous K-pop group (G10).

Similar to the U.S. issue network, the Korean semantic network was composed of many layers. A total of 19 clusters were identified in the Korean semantic network regarding the issue of face masks. As presented in Figure 2, the largest cluster, G1, was about fans' supportive messages and descriptions of K-pop idols' appearances wearing masks and encouraging both celebrities and fans to have protective equipment, expressing appreciation to large corporations for supplying masks during the emergency, and helping bring immigrants back from Japan and Africa. The next large cluster, G2, described criticisms toward the domestic press for framing the government's management of the COVID-19 pandemic in a negative light, while sharing how foreign press highlighted the Korean government's effective management and applauded their capabilities for handling the epidemic situation. The other cluster, G3, consisted of hopeful words about overcoming the challenges caused by COVID-19, and effective prevention through healthcare facilities and technicians' efforts. Interestingly, G4 shows contrasting positions regarding the efficiency of the government's management of the pandemic. Both praise and critical views emerged at the same time. G5 showed positive sentiments toward the public medical care services and disaster-response infrastructure of Korea. Similarly, for G6, patriotic sentiments and criticism of other countries were observed from the Korean users' texts. The users contrasted people in other countries who did not wear masks to Koreans who mostly wore masks to prevent spreading the virus to others during the outbreak. They criticized western countries where wearing masks was not a social norm during the pandemic, and those who were seen without masks were perceived as selfish as they do not seem to 
DRUŠ, ISTRAŽ. ZAGREB GOD. 30 (2021), BR. 2, STR. $359-378$

CHOI, J.A., PARK, S INFODEMIOLOGICAL.. care about protecting others. The other clusters include themes such as a mythical belief that COVID-19 is given by nature to punish humans who damaged the environment (G7), sharing news on elites and experts' criticism on the resistance against wearing masks in Europe (G8), the prevention and treatment of the SARS-CoV-2 infection (G9), and the positive role of foreign press in changing public opinion in Korea about the government's capability in dealing with the COVID-19 outbreak.

\section{DISCUSSION}

The results of the social network analysis indicate that Twitter played a role in fostering public interactions on preventive behaviors during the COVID-19 outbreak. The users relayed information about the current status of the Coronavirus, and suggested adherence to policy and preventive behaviors in both countries. The U.S. network contained a larger public discussion relating to face masks and COVID-19, implying more public concern and anxiety about the disease.

Interestingly, the results of the semantic network analysis suggest that there was a prominent presence of "pro-maskers" along with some "anti-maskers." It should also be noted that the American public refused to heed to CDC's suggestions to reserve N-95 respirators or surgical masks for healthcare providers. In fear of their own safety, as well as confusion due to unclear messaging regarding the effectiveness of cloth face masks, the public expressed the need for medically effective masks for the general public as well. On the other hand, discussions by "pro-maskers" encouraged others to wear masks in public areas and showed negative sentiment toward those refusing to wear masks. This finding implies that wearing masks appears to be a new social norm in the U.S. (Prasad, 2020). For Koreans, the public discourse was largely dominated by applauding the government's management of the pandemic, sufficient supply of respirators and masks, and the acceptance of face masks not just as protective gear, but as a fashion statement. We also found that celebrities and fandom play an important role in wearing masks for Koreans. There was also criticism toward other countries for contributing to the spread and continuation of COVID-19, and jeopardizing global health by not adopting the wearing of face masks as a social norm. These findings may be attributed to Korea's collectivistic culture, which is known to value ingroup norms and comply with social behaviors (Hofstede et al., 2010).

These findings have numerous implications, not only for health agencies, but also in exhibiting the role of technology in identifying the psychosocial aspects of the COVID-19 pan- 
DRUŠ. ISTRAŽ. ZAGREB GOD. 30 (2021), BR. 2, STR. 359-378

CHOI, J.A., PARK, S.: INFODEMIOLOGICAL...

\section{CONCLUSIONS}

demic. Social media analytics can help detect cultural differences and determinants of accepting prevention recommendations. It has revealed the social environment constructed by the pandemic by identifying salient issues related to the public health experts' recommendations. Furthermore, social media analytics can also help formulate effective strategies in risk communication and health campaigns by offering quick, real-time insights and specifying appropriate keywords and hashtags. Especially in a pandemic where prompt yet appropriate decision-making is of essence, this study's findings can offer health experts guidance on future communication strategies regarding face masks by discovering the public's current perception and stance on face masks. A limitation inherent to social network analytics using Twitter is the makeup of Twitter's population. As social media users are not representative of the general public, the study's results may not be generalizable to the general public. As not every Twitter user may contribute to producing tweets, the discourse may be leveraged by only a small group of Twitter users (Park et al., 2016), resulting in a skewed versus the general population's aggregate opinion.

From this study, it is evident that both American and Korean users actively shared information and debated with others on social media about protective measures, specifically wearing face masks, during the current COVID-19 pandemic. As novel infectious diseases are uncharted waters for all, appropriate and timely communication strategies from public health experts are crucial to appease the public's fears and panic, and promote preventive behaviors that help to reduce the spread of the disease. Otherwise, unexpected and retaliatory behaviors that threaten global health security may result as a consequence. This study contributes to identifying socio-cultural and psychological factors underlying public attitudes toward public health policy and suggestions by mining public conversations surrounding face masks on social media. Our findings suggest that in comparison to the Korean users, Americans were more reluctant to wear masks or mocked those who wore masks. This difference may be attributed to the cultural differences between western and eastern cultures, and negative sentiment regarding face coverings, especially in western societies (Prasad, 2020). Fandom of K-pop was one of the major drivers of health information diffusion in the Korean Twitter community. The users engaged in the conversation to entertain themselves and others by sharing their favorite celebrities' appearances with masks. Patriotic senti- 
DRUŠ. ISTRAŽ. ZAGREB GOD. 30 (2021), BR. 2, STR. 359-378

$\mathrm{CHOI}$, J.A., PARK, S. INFODEMIOLOGICAL.. ment associated with government management capabilities and public acceptance of health policies were also prevalent. These psychological factors may have affected the formation of positive attitude and acceptance of health policies. With real-time data aggregation, this study gives insight into the rising controversy regarding wearing face masks during COVID-19 while providing implications for health officials designing strategic communication messages.

Achrekar, H., Gandhe, A., Lazarus, R., Yu, S. H., \& Liu, B. (2012, February). Twitter improves seasonal influenza prediction. In Proceedings of the International Conference on Health Informatics (HEALTHINF-2012) (pp. 61-70). SCITEPRESS.

Alfonson III, F. (2020, April 7). Why some people of color say they won't wear homemade masks. CNN. https://www.cnn.com/2020/04/ 07/us/face-masks-ethnicity-coronavirus-cdc-trnd/index.html

Alicino, C., Bragazzi, N. L., Faccio, V., Amicizia, D., Panatto, D., Gasparini, R., Icardi, G., \& Orsi, A. (2015). Assessing Ebola-related web search behaviour: Insights and implications from an analytical study of Google Trends-based query volumes. Infectious Diseases of Poverty, 4(1), 54. https://doi.org/10.1186/s40249-015-0090-9

Al-Ramahi, M., Elnoshokaty, A., El-Gayar, O., Nasralah, T., \& Wahbeh, A. (2021). Public discourse against masks in the COVID-19 era: Infodemiology study of Twitter data. JMIR Public Health and Surveillance, 7(4), e26780. https://doi.org/10.2196/26780

Bihari, A., \& Pandia, M. K. (2015, February). Eigenvector centrality and its application in research professionals' relationship network. In 2015 International Conference on Futuristic Trends on Computational Analysis and Knowledge Management (ABLAZE) (pp. 510-514). IEEE. https://doi.org/10.1109/ABLAZE.2015.7154915

Blaker, K. (2020, May 4). The new normal - COVID-19, face masks, social stigma. In Good Health. http://www.cnyhealth.com/features/ the-new-normal-covid-19-face-masks-social-stigma/

Borgatti, S. P., Everett, M. G., \& Freeman, L. C. (2002). Ucinet for Windows: Software for social network analysis (Vol. 185). Analytic Technologies.

Bragazzi, N. L., Watad, A., Brigo, F., Adawi, M., Amital, H., \& Shoenfeld, Y. (2017). Public health awareness of autoimmune diseases after the death of a celebrity. Clinical Rheumatology, 36, 1911-1917. https://doi. org/10.1007/s10067-016-3513-5

Buchwald, E. (2020, March, 2). U.S. health officials say Americans shouldn't wear face masks to prevent coronavirus - here are 3 other reasons not to wear them. MarketWatch. https://www.markewatch. $\mathrm{com} /$ story/the-cdc-says-americans-dont-have-to-wear-facemasksbecause-of-coronavirus-2020-01-30

Centers for Disease Control and Prevention (2020a, January 17). Public health screening to begin at 3 U.S. airports for 2019 novel coronavirus ("2019-nCoV"). Centers for Disease Control and Prevention. https://www. cdc.gov/media/releases/2020/p0117-coronavirus-screening.html 
DRUŠ. ISTRAŽ. ZAGREB GOD. 30 (2021), BR. 2, STR. 359-378

CHOI, J.A., PARK, S.: INFODEMIOLOGICAL...
Centers for Disease Control and Prevention (2020b, April 3). Recommendation regarding the use of cloth face coverings, especially in areas of significant community-based transmission. Centers for Disease Control and Prevention. https://www.cdc.gov/coronavirus/2019-ncov/ prevent-getting-sick/cloth-face-cover.html\#studies

Centers for Disease Control and Prevention (2020c, August 7). Considerations for wearing masks. Centers for Disease Control and Prevention. https://www.cdc.gov/coronavirus/2019-ncov/prevent-getting-sick/ cloth-face-cover-guidance.html

Choi, J. A., \& Lewis, R. (2017). Culture and the star-power strategy: Comparing American and Korean response to celebrity-endorsed advertising. Journal of Global Marketing, 30(1), 3-11. https://doi.org/ 10.1080/08911762.2016.1242681

Chung, D. J. (2020, June 16). What South Korea teaches the world about fighting COVID. HBS Working Knowledge. https://www.forbes.com/ sites/ hbsworkingknowledge/2020/06/16/what-south-korea-teaches-theworld-about-fighting-covid/\#4d7f5c9f3e36

Clauset, A., Newman, M. E., \& Moore, C. (2004). Finding community structure in very large networks. Physical Review E, 70(6), 066-111. https://doi.org/10.1103/PhysRevE.70.066111

Cody, E. M., Reagan, A. J., Mitchell, L., Dodds, P. S., \& Danforth, C. M. (2015). Climate change sentiment on Twitter: An unsolicited public opinion poll. PloS ONE, 10(8), 1-18. https://doi.org/10.1371/journal. pone. 0136092

Davidson, E., Edwards, R., Jamieson, L., \& Weller, S. (2019). Big data, qualitative style: A breadth-and-depth method for working with large amounts of secondary qualitative data. Quality $\mathcal{E}$ Quantity, 53(1), 363-376. https://doi.org/10.1007/s11135-018-0757-y

Eysenbach, G. (2006). Infodemiology: Tracking flu-related searches on the web for syndromic surveillance. In AMIA annual symposium proceedings (pp. 244-248). American Medical Informatics Association.

Eysenbach, G. (2009). Infodemiology and infoveillance: Framework for an emerging set of public health informatics methods to analyze search, communication and publication behavior on the Internet. Journal of Medical Internet Research, 11(1), e11. https://doi.org/10.2196/ jmir.1157

Eysenbach, G. (2011). Infodemiology and infoveillance: Tracking online health information and cyberbehavior for public health. American Journal of Preventive Medicine, 40(5), S154-S158. https://doi.org/ 10.1016/j.amepre.2011.02.006

Hall, E. T. (1976). Beyond culture. Doubleday.

Hofstede, G. (1984). Cultural dimensions in management and planning. Asia Pacific Journal of Management, 1(2), 81-99. http://dx.doi.org/ 10.1007/BF01733682

Hofstede, G., Jan, H., \& Michael, M. (2010). Cultures and organizations: Software of the mind. McGraw-Hill USA.

Hong, T., Choi, J. A., Lim, K., \& Kim, P. (2021). Enhancing personalized ads using interest category classification of SNS users based on deep neural networks. Sensors, 21(1), 199. https://doi.org/10.3390/s21010199 
DRUŠ. ISTRAŽ. ZAGREB GOD. 30 (2021), BR. 2, STR. 359-378

$\mathrm{CHOI}$, J.A., PARK, S.: INFODEMIOLOGICAL..
Karami, A., Bennett, L. S., \& He, X. (2018). Mining public opinion about economic issues: Twitter and the U.S. presidential election. International Journal of Strategic Decision Sciences (IJSDS), 9(1), 18-28. https://doi.org/10.4018/IJSDS.2018010102

Lazard, A. J., Scheinfeld, E., Bernhardt, J. M., Wilcox, G. B., \& Suran, M. (2015). Detecting themes of public concern: A text mining analysis of the Centers for Disease Control and Prevention's Ebola live Twitter chat. American Journal of Infection Control, 43(10), 1109-1111. https://doi.org/10.1016/j.ajic.2015.05.025

O'Donnell, J. (2020, February 27). Top disease official: Risk of coronavirus in USA is 'minuscule'; skip mask and wash hands. USA Today. https://www.usatoday.com/story/news/health/2020/02/17/nih-diseaseofficial-anthony-fauci-risk-of-coronavirus-in-u-s-is-minuscule-skipmask-and-wash-hands/4787209002/

Pannell, I. (2020, February 24). Inside the epicenter of the South Korean coronavirus outbreak: Reporter's Notebook. abc NEWS. https:// abcnews.go.com/US/reporters-notebook-inside-epicenter-southkorean-corona virus-outbreak/story?id $=69173992$

Park, H. W., Park, S., \& Chong, M. (2020). Conversations and medical news frames on Twitter: Infodemiological study on Covid-19 in South Korea. Journal of Medical Internet Research, 22(5), e18897. https://doi. org/10.2196/18897

Park, S., Park, J., Lim, Y., \& Park, H. W. (2016). Expanding the presidential debate by tweeting: The 2012 presidential election debate in South Korea. Telematics and Informatics, 33(2), 557-569. https://doi.org/ 10.1016/j.tele.2015.08.004

Perolini, M. (2020, May 26). Is a face mask used to fight COVID-19 really that different from a niqab? Amnesty International. https://www.amnesty. org/en/latest/news/2020/05/face-masks-and-niqabs/

Prasad, R. (2020, May 5). Coronavirus: Why is there a US backlash to masks? BBC News. https://www.bbc.com/news/world-us-canada-525 40015

Rubin, T. (2020, April 7). Coronavirus lessons: How South Korea got face masks for everyone and Germany kept death rate down. The Philadelphia Inquirer. https:/www.inquirer.com/health/coronavirus/coronavirus- masks-shortage-south-korea-germany-fatality-rates-trump20200407.html

Tavoschi, L., Quattrone, F., D'Andrea, E., Ducange, P., Vabanesi, M., Marcelloni, F., \& Lopalco, P. L. (2020). Twitter as a sentinel tool to monitor public opinion on vaccination: An opinion mining analysis from September 2016 to August 2017 in Italy. Human Vaccines $\mathcal{E}$ Immunotherapeutics, 16(5), 1062-1069. https://doi.org/10.1080/21645515.2020. 1714311

Wasserman, S., \& Faust, K. (1994). Social network analysis: Methods and applications. Cambridge University Press. https://doi.org/10.1017/CBO 9780511815478

World Health Organization (2020). Coronavirus disease (COVID-19) pandemic. World Health Organization. https://www.who.int/emergencies/ diseases/novel-coronavirus-2019 
DRUŠ. ISTRAŽ. ZAGREB GOD. 30 (2021), BR. 2, STR. 359-378

CHOI, J.A., PARK, S.: INFODEMIOLOGICAL..
Würtz, E. (2005). A cross-cultural analysis of web sites from high-context cultures and low-context cultures. Journal of Computer Mediated Communication, 11(1), 274-299. https://doi.org/10.1111/j.1083-6101.2006.tb00313.x

Yan, H., Chen, N., \& Naresh, D. (2020, February 21). What's spreading faster than coronavirus in the US? Racist assaults and ignorant attacks against Asians. CNN. https://www.cnn.com/2020/02/20/us/coro navirus-racist-attacks-against-asian-americans/index.html

\section{Infodemiološka studija o upotrebi maski za lice tijekom pandemije COVID-19: usporedba SAD-a i Južne Koreje}

Jin- $\mathrm{A} \mathrm{CHOI}$

Sveučilište William Paterson u New Jerseyju, Wayne, New Jersey

Sejung PARK

Nacionalno sveučilište Pukyong, Busan, Južna Koreja

Usred pandemije COVID-19, dobivamo različite odgovore na preporuke službenika javnoga zdravstva o nošenju maski za lice kao miere koja usporava širenje virusa. Ova se studija koristi podacima s Twittera kako bi istražila ulogu digitalne tehnologije u olakšavanju javne komunikacije i formuliranju percepcije javnosti o nošenju maski tijekom pandemije COVID-19 u dva konteksta: SAD-u i Južnoi Koreji. Od 1. siječnja do 14. travnja 2020. u mreži SAD-a ukupno je 22928 korisnika generiralo 27501 tweet na temu maski za lice, dok ih je u Južnoj Koreji 17267 korisnika proizvelo 18 686. Rezultati analize semantičke mreže otkrivaju početni otpor Amerikanaca prema nošenju maski, kao i spremnost Korejaca da se mjera pridržavaju. Pojedinosti rezultata iznesene su $u$ radu. Uz agregaciju podataka u stvarnom vremenu, ova studija daje uvid u sve veći prijepor povezan s nošenjem maski za lice tijekom pandemije COVID-19, dajući $u$ isti mah informacije zdravstvenim dielatnicima koji oblikuju strateške komunikacijske poruke.

Ključne riječi: infodemiologija, COVID-19, koronavirus, maske za lice, Twitter, društvena mreža

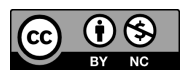

Međunarodna licenca / International License:

Imenovanje-Nekomercijalno / Attribution-NonCommercial 